\title{
Reseña del libro: Desde tu intestino La gran influencia de los diminutos microbios
}

\author{
Rober Knight y Brendan Buhler, (2016). Ed. TED Books —Simon \& Schuster, Inc., New York. 1ra. Edición.
}

ISBN: 978-84-92921-40-9

Los seres humanos estamos compuestos por diez billones de células humanas, pero nuestro cuerpo y en su interior, existen unos cien billones de células microbianas con las que estamos en equilibrio permanente. Diferentes conjuntos de especies habitan en espacios diferentes de nuestro cuerpo. Los microbios que viven en nuestra boca son diferentes a los que residen en nuestra piel o en nuestro intestino y al mismo tiempo, los microbios de nuestra mano izquierda son diferentes a los de nuestra mano derecha. Y por si fuera poco, el 99\% de los genes de nuestro cuerpo pertenecen a nuestros microbios, lo que constituye el microbioma.

En este libro, Robert Knight — director del Microbiome Initiative de la Universidad de California en San Diego y cofundador del Proyecto Intestino Americano y del Proyecto del Microbioma terrestre-y Brendan Buhler galadornado escritor científico cuyo trabajo ha aparecido en Los Angeles Times y Sierra Magazine- nos muestran como el mundo microscópico que habita en el interior de nuestro organismo ofrece la posibilidad de entender la enfermedad, nuestra salud y a nosotros mismos.

Los autores nos describen que nuestro cuerpo es un sistema microbiano ocupado por diferentes tipos de microorganismos. En la nariz y los pulmones podemos encontrar a Stapylococus aureus, en la boca a Streptococos mutans y Fusobacterium nucleatum. En el ambiente sumamente ácido del estómago dónde sobreviven unas pocas especies microbianas podemos encontrar a Helicobacter pylori, quién lleva tanto tiempo viviendo con nosotros que podemos determinar qué poblaciones humanas están más estrechamente emparentadas, y con quién entraron en contacto durante su migración. En nuestro intestino encontramos a la comunidad microbiana más numerosa, y es aquí donde residen Escherichia coli, Firmicutes y Bacteroides. Estas últimas se han vinculado con la obesidad, enfermedades inflamatorias del intestino, cáncer de colon, cardiopatías, esclerosis múltiple y el autismo. Por su parte, los genitales femeninos son sitio de residencia de Lactobacilos.

De manera interesante, los autores también explican que los primeros microbios llegan con el nacimiento y los adquirimos al atravesar el canal del parto de nuestra madre

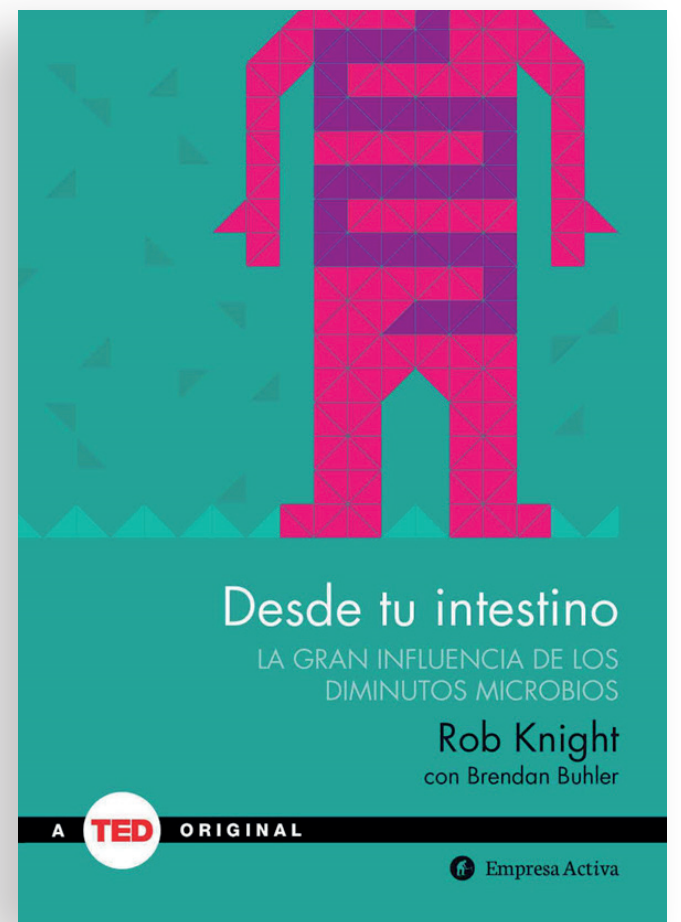


—el cual está cubierto por bacterias vaginales-, mientras que, cuando el nacimiento es por cesárea, los primeros microbios se parecen a los que se encuentran en la piel de los adultos. También nos explican, que las dietas contribuyen a configurar nuestro microbioma, incluso desde las primeras etapas de vida. Un bebé que se alimenta de leche materna está expuesto a microbios especiales que se hallan en la leche de la madre. Bacteroides predominan en los pueblos que siguen dietas ricas en carnes (Estados Unidos y Europa), mientras que Prevotella es más abundante en los intestinos de los individuos con dietas ricas en cereales.

Los autores también describen, la asociación de nuestros microbios con un amplio espectro de enfermedades concretas, desde las evidentes como las enfermedades infecciosas y las enfermedades intestinales, a las sorprendentes, tales como la esclerosis múltiple, el autismo y la depresión. Algunos recientes y fascinantes descubrimientos sugieren que la exposición microbiana durante el embarazo, y no sólo durante la infancia, puede ser un factor importante para reducir las enfermedades alérgicas. Otros resultados prometedores, aunque todavía provisionales demuestran que varios probióticos pueden aliviar la dermatitis atópica y el asma, en particular, Lactobacillus salivarius LS01. Cambiar la microbiota de los animales con antibióticos puede inducir alergias. Ciertas especies de microbios pueden contrarrestar las alergias alimentarias en los ratones o impedir que dichas alergias aparezcan de entrada, mientras que otros pueden provocarlas.

También explican que, desde su trono en los intestinos, los microbios también pueden interactuar con el sistema inmunitario para influir en nuestro cerebro a través del eje cerebro-intestino-microbioma. Se sabe que la depresión conlleva una respuesta inflamatoria, y muchas bacterias beneficiosas del intestino producen ácidos grasos de cadena corta como el butirato, que contribuyen a alimentar las células que recubren el intestino para reducir la inflamación. El microbioma ha sido relacionado muy recientemente con la depresión en humanos gracias al descubrimiento de las bacterias Oscillibacter que producen una sustancia química que actúa como tranquilizante natural, simulando la acción del neurotransmisor GABA, el cual apacigua la actividad nerviosa del cerebro y puede conducir a la depresión. Por otro lado, la capacidad de Mycobacterium vaccae para modular el sistema inmunitario ha llevado a algunos investigadores a sugerir que podría ser utilizado para crear una vacuna contra el estrés y la depresión. Otros estudios demuestran que la molécula 4-EPS es producida en exceso en ratones con microbiomas modificados, los cuales presentan síntomas similares al autismo de los humanos, padecen deficiencias cognitivas, presentan carencias sociales y muestran conductas repetitivas. También se ha demostrado que Bacteroides fragilis contrarresta algunos de los síntomas del autismo, incluidos los problemas gastrointestinales y las deficiencias cognitivas.

Por último, Knight y Buhler nos alientan a recorrer este viaje del descubrimiento microbiano. Entre los descubrimientos que están por llegar cabe destacar los análisis basados en nuestros propios microbios que indicarán como responderás a los analgésicos, fármacos cardíacos y edulcorantes artificiales. Una mejor comprensión de cómo responde tu cuerpo, incluidos sus microbios, a la dieta y al ejercicio, y qué deberías de hacer a nivel personal para estar más sano. Igualmente, se llegará a tener una idea más clara de los trasplantes de materia fecal. Y a un plazo más largo se intentará responder a estas preguntas:

- ¿Podemos diseñar comunidades microbianas que protejan a los humanos de engordar?

- ¿Se pueden diseñar microbios que vivan en nuestra piel y repelan a los mosquitos?

- ¿Pueden ser utilizados los microbios no sólo para diagnosticar sino también para curar enfermedades?

Para responder estas incógnitas y más, cientos de científicos están comprometidos en el proyecto Microbioma Humano, el Proyecto del Microbioma Terrestre y el Intestino Americano. Estos tres proyectos innovadores están preparados para ampliar nuestros conocimientos desde la descripción hasta la prescripción. Las investigaciones venideras aportarán no sólo detallados mapas microbianos de la humanidad, sino también una especie de GPS microbiano, un órgano rector de conocimientos que nos indicará donde estamos, además a dónde queremos ir y cómo llegar hasta ahí.

— Heriberto Torres Moreno- 